\title{
Analysis of country's competitiveness factors based on inter-state rating comparisons
}

\author{
Nadiia Shmygol ${ }^{1}$, Olga Galtsova ${ }^{2}$, Oleksiy Solovyov ${ }^{3}$, Viktor Koval ${ }^{4}$, and I Wayan Edi \\ Arsawan $^{5}$ \\ ${ }^{1}$ Zaporizhzhia National University, Zaporizhzhia, Autozavodska str. 50 fl.13, 69118 Zaporizhzhia, \\ Ukraine \\ ${ }^{2}$ Classic Private University, Dryzba str. 220 fl. 62, 72311 Zaporizhzhia, Ukraine. \\ ${ }^{3}$ Poltava State Agrarian Academy, Pivnichnakilceva Street 11 fl. 79, 69059Poltava Ukraine \\ ${ }^{4}$ Odessa Institute of Trade and Economics of Kyiv National University of Trade and Economics, \\ Odessa, Ukraine \\ ${ }^{5}$ Bali State Polytechnic, Jl. Raya Uluwatu No.45, Jimbaran, Kec. Kuta Sel., Kabupaten Badung, Bali \\ 80361, Indonesia
}

\begin{abstract}
Within the framework of the research was conducted an analysis of the modern level and problems of development of competitiveness, taking into account various aspects and system of advantages. In the article it was proved that despite the wide elucidation of the conceptual apparatus, methodological bases and ways of ensuring the competitive advantages of the respective objects of research, single, generalized point of view on this subject today doesn't exist. It was done the analysis of the factors that ensure the country's competitiveness on the basis of interstate rating comparisons, which made it possible to organize the factors according to the degree of influence by the Pareto's method and to determine priority directions of state development.
\end{abstract}

\section{Introduction}

By definition, the competitiveness of an economic object is its ability to outperform its competitors through a long-term system of benefits under certain operating conditions [14]. Based on this definition, competitiveness is not an absolute but a relative concept. The starting point of the benefits system is the purpose and aims of the research object. It means that one and the same economic object can have a competitive advantage in achieving the same goal and give in to its competitors within another direction of development.

\section{Actual scientific researches and issues analysis and the research objective}

The problem of ensuring the competitiveness of enterprises, taking into account their branch affiliation, was studied in the research of such domestic scientists as: S. Scarlett V.

\footnotetext{
* Corresponding author: victor-koval@ukr.net
} 
Margasova O. Sakun etc. [1]. Sectoral aspect of this problem is reflected in the works: O.Yankovyi, Yu. Goncharov, V. Koval, T. Lositska [2]. At the state level, the competitiveness as a basis for sustainable development was studied by: T. Pulina, Ol. Zerniuk, Al. Glebova etc. [3]. Another direction of the national scientific thought was the problem of ensuring the competitiveness of individual regions. Worthy question in their work was given: Boiko, V., Kwilinski, A., Misiuk, M., Dalevska, N., Khobta, V., Kravchenko, S. [4, 5].

However, despite the broad elucidation of the conceptual apparatus, methodological foundations and ways of ensuring the competitive advantages of the relevant objects of research, there is no single, generalized point of view on this point to date. Not only domestic and foreign scientists, but also foreign research institutes, think-tanks, rating agencies and humanitarian organizations are engaged in study of competitiveness at the level of economic entities, industries and the state as a whole.

According to the purpose of their research, Ukraine holds different competitive positions in the interstate rankings. This, in turn, emphasizes the relative nature of this economic category, and at the same time indicates that there is no definitive consensus among the scientists on the methodology for measuring the indicator and its components.

\section{Assessment and analysis of the competitiveness by international indexes}

According to international rankings, Ukraine's competitiveness in 2018 was evaluated as follows:

1. Global Peace Index (GPI) [6] - according to the Institute for Economics and Peace (Institute for Economics and Peace, IER) in 2018, Ukraine ranked 152 place out of 163 countries in the world. This index has been calculated since 2007 and it is an integral indicator consisting of 15 indicators that characterize the current state and current trends of the peacefulness of countries: participation in the internal or external armed conflicts; the armed forces and international arms trade; crime rate; number of internally displaced persons, etc. On almost all indicators, Ukraine is now forced to give in to other peaceloving countries.

2. Bloomberg's Misery Index (BMI) [7] - according to the Bloomberg Financial News Agency, in 2018 Ukraine ranked $6^{\text {th }}$ place out of 66 countries. The BMI calculation is based on the sum of the projected value level of inflation and unemployment. For Ukraine, this rate was $19.7 \%$ and give in only to Greece $(20.1 \%)$, Turkey (26.8\%), South Africa (31.8\%), Argentina (42.7\%) and Venezuela (929824.5\% with given hyperinflation was taken into account). At the same time, the most prosperous countries mattered at the level of: Thailand (2.1\%), Singapore (2.5\%), Japan (3.4\%), Switzerland (3.6\%) and Germany (4.0\%).

3. World Happiness Report, (WHR) [8] - according to the UN data, in 2018 Ukraine ranked 138th out of 156 countries included in the report. This indicator is calculated on the basis of GDP per capita, the level of social support by the state, average life expectancy, freedom of life choices, generosity and perceptions of corruption. Competitive positions in this index are ensured by the social support of the population. On the other hand, freedom of choice has one of the worst values among all countries in the world. WHR of Ukraine made 4,103 points, Sudan $(4,139)$ and Togo $(3,999)$. Compared to other countries, WHR of Finland was 7,632 points, Norway - 7,594, Burundi - 2,905.

4. Prosperity Index (LPI) [9] - According to the data of British think tank The Legatum Institute, Ukraine ranked 111 th out of 149 countries. This index has been calculated since 2008 and is an indicator of the well-being of the population of a country. It is based on a system of more than 100 indicators, grouped by areas: level of economic development, 
business conditions, activities of government effectiveness, education, health care, life safety, level of personal liberties in society, social capital and ecology. The most troublesome, according to the results of 2018, were recognized government performance indicators (129th among other countries), life safety (128th place) and health care (137th place); the most competitive are education (43th place) and the level of personal freedom (90th place).

5. Human Development Index (HDI) [10] - According to the UN, today Ukraine ranks 88th among 189 countries. HDI includes such components as: average life expectancy; the level of education of the society determined by the length of study; the standard of living of the population equals to the gross national income per capita at the compound prices of the base year. Competitive positions of Ukraine, in comparison with other countries, are ensured due to the duration of study, which on the average 26.3 years. This indicator does not inferior to the level of highly developed countries in Western Europe. As for the last two indicators, we have a significant backlog:

- The average life expectancy in Ukraine is 72.1 years, with a maximum life expectancy 83.6 years in Switzerland. However, in the vast majority of developed countries, this figure exceeds 80 years;

- GNI per capita is \$ 8130, in Liechtenstein is \$ 97336 and \$ 82,503 in Singapore. However, almost in all countries of Western Europe, this figure exceeds $\$ 30,000$.

6. Social Development Index (SPI) [11] - According to the US data of think tank Social Progress Imperative, in 2018 Ukraine held 64th position among 146 countries, gaining 69.30 points out of 100 . For comparison, among the leading countries, Norway scored 90.26 points, Denmark - 90.10 points. The lowest rated countries are Chad - 28.20 points and Central African Republic - 26.01 points. The Social Development Index consists of three areas of research containing 51 indicators:

- basic human needs (81.48 points): food and basic medical care (93.74 points), water and sanitation ( 90.59 points), shelter ( 85.79 points), personal safety (55.80 points);

- basics of well-being (69.38 points): access to basic knowledge (90.54 points), access to information and communications (73.46 points), health and well-being (56.12 points), environment (57, 41 points);

- opportunities (57.04 points): personal rights (73.01 points), freedom of choice (66.01 points), inclusivity (35.61 points), access to higher education (53.52 points).

- The results of this study show that in social development, Ukraine is far inferior to other countries in terms of personal safety, environmental pollution, access to a quality health care system and inclusiveness. The last refers to equality of political power in socioeconomic status and discrimination to violence against minorities.

7. Index of Economic Freedom (IEF) [12] - calculated by The Heritage Foundation of American Research Center since 1995 for 180 countries in the following areas: rule of law; the number of authorities that govern the country and the effectiveness of its activities; open markets and more. In total this index includes 12 indicators, 3 in each group. As a result of their convolution, the IEF takes values from 0 to 100 points and can be interpreted as follows:

- from 80 to 100 points - free countries. This group, based on 2018, includes Hong Kong (90.2 points), Singapore (89.4 points) and New Zealand (84.4 points)

- from 70 to 79.9 points - almost free countries. This group includes 28 countries in Europe, Asia and North America with developed market economies;

- from 60 to 69.9 points - moderately free countries. This value of the IEF index, first of all, is characteristic of developing countries: Bulgaria, Romania, Poland and others. However, some developed countries with market economies are also included in this group: Spain, France, Italy, etc.; 
- from 50 to 59.9 points - mostly non-free countries. Ukraine ranks 147 th in the overall interstate rating and gains 52.3 points. Along with it, according to the index of economic freedom, are such countries as: Gambia, Argentina, Brazil, Afghanistan, Iran, Angola and others. It should also be noted that Ukraine is close to the lower boundary of the interval, that is, to countries with the lowest IEF; - from 40 to 49.9 points - non-free countries: Chad, Liberia, Turkmenistan, North Korea and others.

This index shows that Ukraine is significantly inferior to countries with developed market economies. The greatest problems are inherent in the rule of law, investmen and financial freedom, as well as the free choice of employment.

8. Global Doing Business Rating (DB) [13] - calculated by the World Bank for 190 countries around the world and provides for their comparative assessment of regulatory organization conditions and doing business. The DB calculation methodology is based on 44 indicators grouped by 10 directions of assessment. Some areas are associated with the implementation of certain stages of doing business. Therefore, their indicators take into account: the required number of procedures for cooperation with state bodies; regulated lead time and cost of implementation. Thus, according to the DB calculation, Ukraine occupies the following competitive positions in the ratings, where the lower rating corresponds to the higher value:

- Business registration - 56 place;

- Obtaining permits for construction of objects - 30th place;

- Easiness of connection to the power supply systems - 135 place;

- Property registration - 63;

- Credits obtaining - 32 place;

- Protection of minority investors - 72 place;

- Tax system - 54 place;

- International trade - 78th place;

- Contract execution - 57th place;

- Solution of insolvency issues - 145th place.

To sum up, in 2018, Ukraine ranked 71st in this ranking, gaining a total of 67.31 points. At the same time, the leaders of the rating scored: New Zealand - 86.59 points; Singapore 84.97 points and more. The countries close to Ukraine are Vietnam, Greece, Mongolia, Uzbekistan and India.

A significant lag was observed in the ease of connection to the power supply systems and the solution of insolvency issues. On the other hand, the greatest competitive advantages were obtaining building permits and ease of obtaining loans.

9. Global Innovation Index (Global Innovation Index, GII) [14] - calculated by Cornell American University from 2007 till the present and includes information about achievements in innovation activity, taking into account political situation, educational level, business development and infrastructure. In 2018, Ukraine ranked 43rd place out of 126 countries in the world and 30th out of 39 in Europe. The main components of this index are:

- institutions (107th place in the overall interstate rating) - measures the effectiveness of the political, regulatory and business environment in the functioning of the economy;

- human capital and research (43 place) - measures the development of primary and higher education, as well as exploration and scientific research;

- Infrastructure (89th place) - assesses the development of information and communication technologies, general infrastructure and environmental sustainability of the country;

- Market (89th place) - characterizes the development of the financial capital market in the country, the conditions for conducting investment activities and the development of competition and the size of the internal market; 
- Business (46 place) - assesses the qualification of employees and the level of implementation of innovative knowledge in the activities of subject management.

- All the above components characterize in GII the first direction of evaluation - the level of innovation, that is, the measures that should contribute to the growth of the target. According to it Ukraine took 75th place.

- In addition, in the GII, the second direction of evaluation is the level of innovative results or achievements in the innovation field. In 2018, Ukraine ranked 35th. It includes the following components:

- creation of new knowledge and technologies (27th place) - indirectly evaluated the amount of new knowledge, their impact and dissemination in the economy;

- production of creative products (45th place) - consists of intangible assets, creative goods and services, as well as implementation of online services.

- The relative comparison between innovative activities and results shows that during the reporting period Ukraine has shown high efficiency of converting its innovative activity into the final result. This ratio is measured by the innovation efficiency coefficient, by which Ukraine ranks $5^{\text {th }}$ place in the world.

10. Global Economic Competitiveness Index (GSI) [15] - calculated on the initiative and methodology of the World Economic Forum, where in 2018 Ukraine ranked 83rd place out of 140 countries, scoring 57 points out of 100 possible. Today the CGI index calculation is one of the most comprehensive and detailed international comparisons, based on about 100 indicators in all spheres of economic activity, innovative and social development of the country. According to the authors research, the competitiveness of the state is conditioned by such factors as:

- environment - legal institutions (110th place), infrastructure development (57th place), the spread of mobile and Internet technologies (77th place), macroeconomic stability (131st place);

- human capital - health (94th place) and work skills (46th place);

- market - trade and trade barriers (73 place), labor market (66 place), financial system (117 place), gross domestic product (47 place);

- innovative ecosystem - business liberalization (86th place), innovative opportunities (58th place).

\section{Definition of the competitiveness profile of Ukraine}

An assessment of Ukraine's competitiveness by international rating [12-15] and analysis of the works of leading scientists $[18,19]$ allowed to clarify the following problems of the concept development at the methodological level:

- an economic category "competitiveness of the country" is a multifaceted concept by which the assessment and interstate comparison of different socio-economic aspects of the world regions development and living conditions of the population are being implemented. In practice, this means big differences in the system of indicators of such assessment, depending on the purpose of the study;

- as a rule, the components of each competitive index based on international comparisons are the sets of different economic points, units of measurement and methodology for calculating indicators. Certain sets of indicators can be obtained from the national statistical reporting of the surveyed countries on the basis of open access data. Other groups of indicators can be obtained from the public reporting of various international organizations. Individual indicators can only be calculated on the basis of an indirect estimate since there is no reliable data on their status. As a result, the accuracy of the calculations, the objectivity and the reliability of the values obtained for each specific indicator of analysis can be significantly different from each other. This, of course, has a 
negative effect on the results of the generalized assessment, as the degree of its uncertainty increases;

- The composition of countries' competitiveness of international indices which were considered in the previous study is not constant and may change over time due to objective and subjective reasons.

- Modern technological development on the background of rapid globalization processes over time objectively changes the system of priorities that determine the competitive advantages of a region of the world. On the other hand, in this case, the subjects of evaluation can be certain expert environments, whose conclusions always have subjective character. As a result, calculating methodologies for international indices are constantly being refined and modified, making it difficult to retrospectively analyze their dynamics over time.

- Management of the competitive development of a country on the basis of international ratings is complicated by the fact that in some cases, the methodologies of their calculations in open access are not sufficiently complete and do not allow to restore the entire sequence of calculations.

- Given the above, justifying the many factors that affect country's competitiveness is an important scientific task that needs to be solved.

- From the theory of economic analysis, it is known that any indicator system should include indicators that:

- firstly, describe as fully as possible all studied aspects of the economic phenomenon or object;

- secondly, they should not have functional connections with each other;

- thirdly, they are calculated on the basis of reliable statistical information.

Since conducting interstate comparative analysis of Ukraine's competitiveness level is problematic from a technical point of view, a valid study should foresee an analysis of the dynamics of the target indicator at the expense of the factors that determine its status.

It should also be considered that state-level competitiveness assessments help to identify general trends in the effectiveness of socio-economic development, which is an indicator of the national average level. However, any economic development is not homogeneous. Both centers of growth and decline can be distinguished by certain characteristics. That is why there is a need to further refine the target by the most significant features.

A preliminary study of the international competitiveness ratings of the countries of the world showed that the greatest attention of scientists was attracted by the macroeconomic development of the regions, which in turn is ensured by the manufacturing sector and its efficiency. That is why, in the framework of this work, it is proposed to perform an analysis of competitiveness by sectoral indication.

At the same time, the territory of Ukraine is also very heterogeneous on a regional indication.

Each region is characterized by certain natural and climatic conditions of existence, development of industry and labor resources, social security of the population, which directly affects the level of its competitiveness [24]. Therefore, the regional aspect should also be taken into account when analyzing the target indicator.

In view of the above, we will analyze the current level of competitiveness of Ukraine as a whole and at the sectoral level by the main socio-economic indicators of development, energy and the environment [20-23; 25].

Economic growth, which is indisputably an indicator of the competitiveness of any country's economy, is measured by the gross domestic product. The disadvantage of this indicator is that it covers only the quantitative side of this phenomenon, without taking into account the effectiveness of changes that occur. It is understood that through the factors, whether intensive or extensive, economic growth is being achieved. 
Taking into account the above, in Fig. 1 is shown the competitiveness profile of Ukraine according to GCI data. On the main vertical axis, Fig. 1, points from 0 to 100 are marked. All factors of Ukraine's competitiveness are streamlined by the decrease in the number of scored points. Higher scores indicate better socio-economic status according to this area of assessment. However, the immediate number of points does not allow us to assess Ukraine's competitive advantages to compare with other countries because they are not relative indicators or comparison. In other words, the large number of scored points is not yet an indication that the country is not inferior within this factor to other states and vice versa.

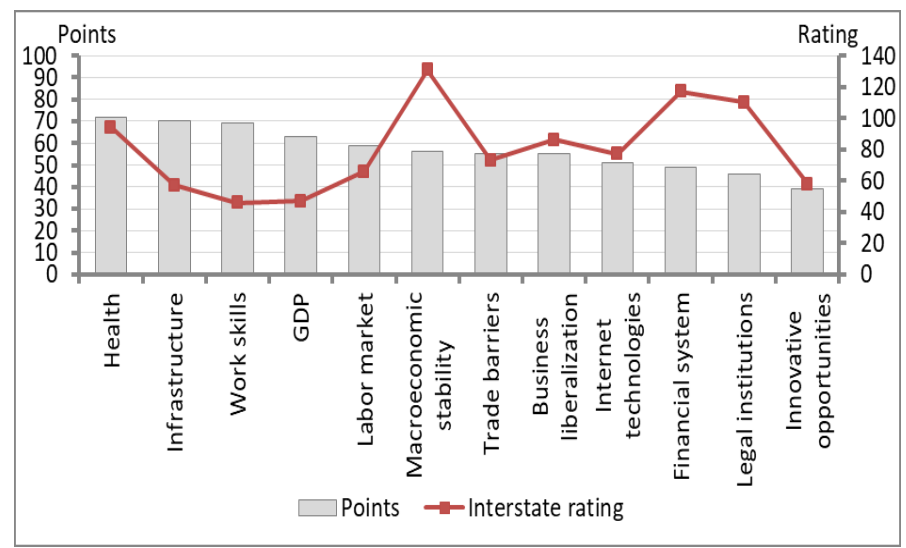

Fig. 1. Competitiveness profile of Ukraine according to 2018 data

Therefore, along the auxiliary vertical axis, Fig. 1, for each direction of assessment, the corresponding rating of Ukraine was noted, which can take values from 1 to 140 . The combination of the maximum number of scored points and the lowest value of the interstate rating will indicate sustainable socio-economic development, which precedes other countries, namely, is a criterion for competitiveness.

\section{Definition of the most competitive factors of development of the national economy by Pareto criteria}

Since one of the indicators is quantitative and the other is qualitative, it is possible to determine the most competitive factors for the development of the national economy by the Pareto criterion, which provides a procedure for pairwise comparison:

- to the plural factors of Pareto I group were included health, infrastructure, and work skills. They are not comparable between each other because the decrease (deterioration) of the number of points is accompanied by a decrease (improvement) of the interstate rating and vice versa. Therefore, according to these factors, Ukraine is the most competitive in comparison with other countries of the world;

- Gross domestic product is included to plural factors of Pareto II group. Although GDP is not comparable to health factors and infrastructure, it is strictly inferior to work skills, which are also in the I group. Therefore, in terms of health and infrastructure, Ukraine's competitiveness is not inferior to GDP factor;

- to the plural of Pareto III group are included: the labor market and innovative opportunities;

- to the plural of Pareto IV group are included: macroeconomic stability, trade barriers and business liberalization; 
- to the plural Pareto V group are included level of distribution of mobile and internet technologies;

- to the plural of Pareto VI group are included the financial system and legal institutions. As this is the last set of factors, Ukraine is the least competitive behind them, so they need the most attention.

They include the following GCI indicators, which have demonstrated the worst competitive positions: domestic loans to small and medium businesses, venture capital, financial stability of the Ukrainian banking system, portfolio of inefficient loans, organized crime, homicide and terrorism, social independence, social independence corruption, protection of property rights and intellectual property, etc.

\section{Conclusion}

Thus, in view of the international ratings, in the framework of this study we conducted an analysis of the current level and problems of development of Ukraine's competitiveness, taking into account various aspects and system of advantages.

In his work, it was further development of analysis of the factors ensuring the competitiveness of the country on the basis of interstate rating comparisons was obtained, which unlike the existing ones allowed to organize the factors according to the degree of influence by the Pareto method and to determine priority directions of the state development.

\section{References}

1. S. N. Shkarlet, O. V. Marhasova, O. S. Sakun, Scientific Bulletin of Polissia 3 (7), 2937 (2016)

2. T. Pulina, O. Zerniuk, A. Glebova, International Journal of Engineering \& Technology 7 (4.8), 226-229 (2018)

3. O. Yankovyi, Yu. Goncharov, V. Koval, T. Lositska, Naukovyi Visnyk Natsionalnoho Hirnychoho Universytetu 4, 134-140 (2019)

4. V. Boiko, A. Kwilinski, M. Misiuk, L. Boiko, Economic Annals-XXI 175(1-2), 68-72 (2019)

5. N. Dalevska, V. Khobta, A. Kwilinski, S. Kravchenko, Entrepreneurship and Sustainability Issues 6(4), 1839-1860 (2019)

6. Global Pease Index 2018 (2019). Vision of Humanity, URL: http://visionofhumanity.org

7. Bloomberg's Misery Index 2018 (2019). These Are the World's Most Miserable Economies, URL: https://www.bloomberg.com

8. J. Helliwell, R.Layard, J. Sachs, (2019). World Happiness Report 2019, New York: Sustainable Development Solutions Network, URL: https://worldhappiness.report/ed/2018/

9. The Legatum Prosperity Index 2019 (2019). Legatum Institute Prosperity, URL: https://www.prosperity.com/rankings

10. Human Development Index 2018 (2019). United nations development programme, URL: http://hdr.undp.org

11. Social Progress Index 2018 (2019). The Social Progress Imperative, URL: https://www.socialprogress.org 
12. Index of Economic Freedom 2018 (2019). The Heritage Foundation, URL: https://www.heritage.org

13. Doing Business 2018 (2019). The World Bank Group, URL: https://russian.doingbusiness.org

14. Global Innovation Index 2018 (2019). World Intellectual Property Organization, URL: https://www.wipo.int

15. Global Competitiveness Index 2018 (2019). World economic forum, URL: http://www3.weforum.org

16. V. Koval, Y.Sribna, K. Gaska, E3S Web Conference 132, 01009 (2019). https://doi.org/10.1051/e3sconf/201913201009

17. V. Koval, K. Kostetska, N. Khumarova, Yu. Umanska, N. Shmygol, Institutional qualities of inclusive environmental management in sustainable economic development, Management Systems in Production Engineering (to be published)

18. I. Perevozova, N. Shmygol, D. Tereshchenko, K. Kandahura, O. Katerna, Journal of Security and Sustainability Issues 9(1), 139-154. Retrieved from: https://doi.org/10.9770/jssi.2019.9.1(11) (2019)

19. M. Yeshchenko, V. Koval, O. Tsvirko, Espacios 40 (38), 11 (2019).

20. V. Koval, G. Duginets, O Plekhanova, A. Antonov, M. Petrova, Entrepreneurship and Sustainability Issues 6(4), 1922-1937 (2019).

21. V. Koval, N. Kovshun, O. Plekhanova, S.Kvitka, O. Haran, 19th International Multidisciplinary Scientific Geo Conference SGEM 2019 19(5.3), 877-884 (2019)

22. I. Gryshova, M. Petrova, M. Tepavicharova, A.Diachenko, T. Gutsul, Entrepreneurship and Sustainability Issues 7(1), 690-703 (2019)

23. V.Koval, Y. Sribna, O. Mykolenko, N. Vdovenko, 19th International Multidisciplinary Scientific GeoConference SGEM 2019 19(5.3), 283-290 (2019)

24. O. Luchaninova, V. Koval, H. Deforzh, L. Nakonechna, O. Golovnia, Espacios 40 (41), 11 (2019).

25. K. Nazarova, V. Mysiuk, V. Hordopolov, N. Novikova, V. Koval, I. Danilevičiene, Preventional audit: implementation of sox control to prevent fraud, Business: Theory and Practice (to be published) 